\section{Validation of Scales to Research the Personal Financial Management}

\author{
Ricardo Teixeira Veiga ${ }^{1}$ \\ Cátia Avelar' \\ ${ }^{1}$ Federal University of Minas Gerais, Faculty of Economic Sciences, Center \\ and Research in Administration, Belo Horizonte, Brazil \\ Luiz Rodrigo Cunha Moura ${ }^{2}$ \\ ${ }^{2}$ University Center UniBH, Department of Administration, \\ Belo Horizonte, Brazil
}

\section{Agnaldo Keiti Higuchi ${ }^{3}$}

${ }^{3}$ Federal University of Jequitinhonha and Mucuri Valleys, Faculty of Applied and Exact Social Sciences, Administration Department, Teófilo Otoni-Brasil

\begin{abstract}
Purpose - The paper describes the test of preexistent scales to measure behaviors of personal financial management, buying impulsiveness and financial strain

Design/methodology/approach - From the back translation of scales published in English, empirical research was carried out to certify the reliability and validity of these instruments. A survey through the internet was performed with 195 respondents (postgraduate students and teachers from five Brazilian states, related to business administration courses). Data were analyzed with exploratory and confirmatory factor analysis, in addition to structural equation modeling, using the statistical software IBM SPSS and AMOS.
\end{abstract}

Findings - The scales are reliable and showed construct validity. In the examination of scales' nomological validity, there is a negative association between buying impulsineness and financial management. Financial manegement this construct has a negative effect on financial strain, and partially mediates the positive relationship between impulsiveness and financial strain.

Originality/value - Results motivate the use of a scales of the behavior of personal financial management in order to evaluate this trait of personal competence, supporting programs of financial education and the marketing planning of credit institutions.

Keywords - Personal Financial Management. Financial Strain. Buying Impulsiveness. Scales' Validation.
Received on

03/12/2018

Approved on

$11 / 30 / 2018$

Responsible editor:

Prof. Dr. Javier Montoya

Evaluation process:

Double Blind Review

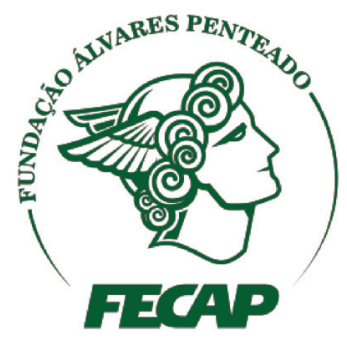

Review of Business Management 


\section{Introduction}

Consumers make decisions about purchases, payments, and the management of their financial resources. Their quality of life and that of their family members are strongly affected by their competence in financial management. But they are often ill-informed and prone to making mistakes that have heavy individual and social consequences, such as not saving enough for retirement, overspending, not paying bills on time, and regretting purchases (Lynch, 2011; Strömbäck, Lind, Skagerlund, Västfjäll, \& Tinghög, 2017).

The rise in Brazilians' indebtedness seems to be linked to factors such as the increase in the population's optimism and ease of getting credit (Campara, Vieira, \& Ceretta, 2016; Figueira \& Pereira, 2014). Moreira and Carvalho (2013) showed that factors such as inflation control and the opening up of the economy, which made the entrance of new products into the national market possible, together with the credit expansion, boosted the rise in consumption and personal indebtedness. According to a survey by the National Confederation of Trade in Goods, Services, and Tourism (CNC, as abbreviated in Portuguese), in October of 2017, more than $60 \%$ of Brazilian families had debts (credit card, pre-dated checks, personal loans, or car payments etc.), and $26 \%$ of these families had overdue bills.

As possible results of bad personal finance management, indebtedness and default may cause negative effects both at the macroeconomic level, by increasing the risk of financial operations and products, and individually, by affecting social relations, psychological state, and family life (Falahati, Sabri, \& Paim, 2012; Serviço de Proteção ao Crédito [SPC] \& Confederação Nacional de Dirigentes Lojistas [CNDL], 2017; Trindade, Righi, \& Vieira, 2012; Zimmerman, 1995).

According to Mills, Grasmick, Morgan, and Wenk (1992), financial strain (abbreviated as FS), that is, the personal perception of maladjustments, financial problems, and worries, is an important indicator of a lack of psychological well-being. Indeed, a high level of financial strain is often associated with high levels of physical and psychological stress (Mendes-da-Silva, Nakamura, \& Moraes, 2012), which diminish the population's financial satisfaction (Zimmerman, 1995).

Proper personal financial management (or merely financial management or PFM) may prevent or diminish financial strain. Because of this, financial education to improve PFM practices should raise the population's financial satisfaction and quality of life.

The emergent interest of marketing academics in topics concerning PFM (Figueira \& Pereira, 2014; Lynch, 2011; Miotto \& Parente, 2015) highlights the importance of their research. For example, Figueira and Pereira (2016) found an influence of attitudes towards credit cards on proclivity to indebtedness. Miotto and Parente (2015) researched how São Paulo families manage their finances, revealing unique behaviors of Class C female consumers: an inadequate focus on financial control, a lack of attention to short and mid-range planning, an overall absence of saving, and the influence of critical events in cases of default.

Despite the increase in specific Brazilian publications, the scales used in most studies have not encompassed sufficient factors to evaluate the behavior of financial management in its complexity, i.e., behaviors regarding savings and investments, insurance purchases, cash flow management, and credit management, all of which can characterize appropriate financial resource management.

In order to increase the research on PFM, it is necessary to use proper research instruments. Scale constructs regarding financial management are necessary to evaluate models and develop theories. However, the validation of scales is fundamental, and should involve studying independent samples, instead of being limited to the secondary result of testing models with the same sample in a cross-sectional study, as 
is usually done. Employing the same sample to achieve both exploratory goals (assessment and improvement of measures) and conclusive ones (test of hypotheses) might produce illusory results, known as statistical artifacts.

Although Dew and Xiao (2011) created a scale to operationalize the behavior of PFM (see Table 1), new studies must confirm their results and, to use the scale in Portuguese, it must be translated and its psychometric properties tested.

The pivotal objective of this paper is to describe the empirical test of the PFM behavior scale (Dew \& Xiao, 2011), by evaluating its factor structure, reliability, and validity. Due to this objective and to the overall interest in providing useful scales to perform research on PFM, we translated the scale into Portuguese and backtranslated it into English to ensure congruence, and we validated two constructs associated with this behavior - Purchase Impulsiveness and Financial Strain - that were based on pre-existing scales, respectively proposed by Weun, Jones, and Beatty (1997) and Mills et al. (1992). The empirical test of the scales employed statistical procedures briefly presented in the chapter about the research method.

In short, the contribution sought in this paper is twofold: 1) to describe the scale validation procedures, presenting the most usual statistical indexes, in order to support the development of competence in research; and 2) to offer to Brazilian researchers three validated scales, one of them unprecedented in Portuguese, with high potential for application in personal financial management studies.

In social terms, investigating the antecedents and consequents of PFM is important because competence in this field might reduce the negative effects of a lack of money. Moreover, knowledge of the characteristics of financial behavior may help in the development of financial education programs aimed at increasing the population's quality of life. For example, such knowledge could support programs that help in the wise use of credit, management of cash flows, and savings behavior to improve PFM, thus reducing financial problems and the resulting stress. Knowledge of the dimensions of the behavior of PFM may also be useful for financial institutions, by providing information for segmenting consumers according to their profile and behavioral pattern. Therefore, knowledge of PFM behavior is of interest to academics, managers, and people involved with wellbeingoriented public policies (Lynch, 2011).

\section{Theoretical Framework}

\section{I Personal financial management}

Lynch (2011) explains that consumers' decisions about their finances are related to aspects such as (1) patterns of spending and resource allocation for either simple or complex purchases, (2) credit use, indebtedness, and debt payment behaviors, and (3) behaviors concerning saving and investments. Imbalances between revenue generation and spending in a specific period produce savings, money for investments, or debts.

PFM behaviors concern purchase decisions and practices, investments, loans management etc. Dew and Xiao (2011) say that people tend to adopt effective financial management behaviors in an interrelated way, for example, cash flow management and credit habits. However, when revenue is insufficient, individuals may not save or keep a financial reserve for emergencies or retirement, nor have proper insurance. It must be stressed that besides social factors such as an abundance of credit, consumerism, and materialism, individual personality characteristics and education favor inappropriate behaviors in PFM, resulting in undesired consequences such as hasty decisions, waste, and indebtedness.

Many studies show that consumer financial decisions are influenced by factors such as skills and personal traits, situational factors, and social motivations. In addition to the previously quoted research, studies regarding topics in PFM and financial satisfaction (e.g., Amar, Ariely, Ayal, Cryder, \& Rick, 2011; Archuleta, Britt, Tonn, \& 
Grable, 2011; Joo \& Grable, 2004; Kamleitner, Hoelzl, \& Kirchler, 2012; Norvilitis et al. 2006) have been published abroad. The Journal of Marketing Research issued a special edition about consumer financial decisions in November 2011.

Results based on representative American adult data, presented by Tang and Baker (2016), suggest that self-esteem is significantly correlated with individual financial behavior, after controlling for financial knowledge and other socioeconomic factors. Farrel, Fry, and Risse (2015) found that financial self-efficacy is one of the strongest predictors of the type and number of financial products that an Australian woman has. According to the authors, Australian women with more financial self-efficacy are more inclined towards financial investments and savings and less prone to keeping products that foster indebtedness.

Recently in Brazil, research publications about PFM have increased. Campara et al. (2016) identified the influence of behavioral and socioeconomic variables on a positive attitude towards indebtedness among residents of cities in the Brazilian state of Rio Grande do Sul. Faleiro, Fürh, and Kronbauer (2015) studied the financial behavior of public and private high-school students in Rio Grande do Sul. Piccoli and Silva (2015) measured the level of employees' financial education at higher education institutions in the Brazilian state of Santa Catarina. Figueira and Pereira (2014) analyzed the conditioning factors (attitude towards money, attitude towards credit cards, self-control, impulsive buying) of consumer indebtedness. Norvilitis and Mendes-da-Silva (2013) compared Brazilian students to American ones, aiming to use the theory of planned behavior to forecast debts caused by credit card use and the self-perception of financial well-being. In addition to the aforementioned studies, the research on PFM by Medeiros, Diniz, Costa, and Pereira (2015), Medeiros and Lopes (2014), Mendes-daSilva et al. (2012), Moreira and Carvalho (2013), and Trindade et al. (2012) deserve attention.

\subsection{Impulsiveness}

According to Rook and Fisher (1995), impulsiveness is the tendency to act spontaneously, quickly and without pondering. Buying impulsiveness (hereafter abbreviated as $\mathrm{BI}$ ) is the predisposition to buy on impulse, without planning, in an unreflective and automatic way (Weun et al., 1997), which is related to a pattern of PFM.

Some authors have shown the relationship between BI and PFM. For example, to measure the human brain's executive functions in PFM, Spinella, Yang, and Lester (2007) developed a four-factor scale (impulse control, organization, planning, and motivation), with two second-order factors (a cognitive factor related with planning and organization, and an emotional factor related with anxiety, impulsive spending, and prestige).

Strömbäck et al. (2017) say that selfcontrol is typically manifested as the skill to break bad habits, resist temptation, and overcome initial impulses, such that financial behavior is determined by the skill to control impulses and costs through practicing self-control. The authors investigated the effect of the individual differences in self-control and other non-cognitive factors on the financial behavior and wellbeing of the Swedish population, with the following results: individuals with good self-control are more liable to save part of their income; they have better financial management skills, are less anxious about financial matters, and more secure about their financial situation. As impulsive behaviors indicate a lack of or failure in selfcontrol, impulsiveness can affect financial resource management.

In a study of São Paulo's class C females, Miotto and Parente (2015) showed that women with more self-control and a greater inclination to plan are more capable of managing their finances; if they are indebted, this is mainly explained by a financial imbalance or by critical events such as job loss or divorce.

In their literature review regarding credit card use, Kamleitner et al. (2012) show that the 
behavioral traits of Self-Control and Difficulty in Postponing Gratifications, which is typical of Impulsiveness, are useful for forecasting the use of credit.

These empirical results about the relationship between impulsiveness and financial behavior led to the elaboration of the first research hypothesis, used in the nomological validation of the PFM scale, proposed by Dew and Xiao (2011):

H1: BI (Buying Impulsiveness) has a negative effect on the PFM.

\subsection{Financial strain}

Satisfaction with one's personal financial situation enhances quality of life. Because of this, it is an important goal of family policy (Zimmerman, 1995). People with proper financial behavior are less prone to financial stress and have higher levels of financial satisfaction and financial well-being (Joo \& Grable, 2004; Norvilitis et al., 2006).

In Brazil, studies on credit and indebtedness have addressed the relationship between PFM behaviors and personal problems caused by poor financial management. The results of a national study, in June 2017, showed that indebted people have serious psychological and social problems, which range from insecurity and irritability to anxiety, anguish, loss of appetite, depression, and unhappiness (CNC, 2017; SPC \& CNDL, 2017), i.e., they have more financial stress.

In order to assess the predictive and nomological validity of the PFM construct, we hypothesized its inter-relationship with the BI and FS constructs, taking into account these empirical results:

H2: BI has a positive effect on Financial Strain (FS).

H3: PFM has a negative effect on Financial Strain (FS).
Note that our objective was to validate scales, in Portuguese, to apply in future research, with an emphasis on the PFM scale. The use of an antecedent and a consequent of this construct aims to help its nomological and predictive validation, based on the expectation of supporting effects made evident in the literature.

\section{Method}

Despite the importance of measure validation in science, research about the personality and other psychological constructs often does not follow the best practices, as authors limit themselves to reporting the measures' reliability index (Flake, Pek, \& Hehman, 2017).

Construct validation simultaneously involves the measurement process and theory validation because construct validation tests based on hypothetical relations reflect both its validity and the underlying theory (Strauss \& Smith, 2009).

At least three steps are essential for construct validation: 1) theoretical specification of constructs and of their interrelationship, 2) elaboration of methods for construct operationalization, and 3) empirical testing of how well the constructs reflect their identity and theoretical relations (Cronbach \& Meehl, 1955).

According to Netemeyer, Bearden, and Sharma (2003), dimensionality, reliability, and validity are interrelated measurement properties. Dimensionality is the number of factors represented by items or a scale's indicators. A construct is uni or multidimensional. The construct's operationalization must represent its factor structure. Unidimensionality is a requisite for reliability and validity of a one-factor construct; therefore, it must be confirmed with exploratory factor analysis (Netemeyer et al., 2003). The authors explain that reliability is the consistency or stability of measures. That is, the more reliable a measure is, the less it has a random error. To certify the reliability of a measure, either testing-retesting might be used or internal reliability measures such as Cronbach alpha can be employed (Netemeyer 
et al., 2003). Finally, construct validity reflects how well a construct measures what it claims to be measuring. Construct validity tests include face, convergent, discriminant, and nomological validity tests.

In the case of preexisting and validated constructs, new empirical studies are required to confirm the results and certify adaptations or translations of measures into other languages.

In 2016, we performed a survey over the internet to validate the PFM, BI, and FS scales, based on the hypotheses of their interrelationship. We obtained answers from 195 graduate students and post-graduation teachers from the Brazilian states of Amazonas, Espírito Santo, Minas Gerais, Paraná, and São Paulo. The project met ethical standards (Academia Brasileira de Ciência $[A B C]$, 2013), and the qualified respondents were adults, who received salaries or equivalent incomes.

During the data collection, to avoid respondent fatigue and reduce the likelihood of response bias, we adopted different 7-point scale formats in the operationalization of the constructs (Podsakoff, Mackenzie, Lee, \& Podsakoff, 2003). Only in the case of questions regarding the PFM construct did we add the option "not applicable" in the answers.

To measure BI, we used the Weun et al. (1997) scale. The authors carried out three studies to develop the scale, gathering evidence of its unidimensionality, internal reliability, and convergent and discriminant validity. Due to these psychometric qualities, we translated its five items from English to Portuguese and back-translated to English to ensure consistency.

P1: When I go shopping, I buy things that I had not intended to purchase.

P2: It is fun to buy spontaneously.

P3: I am a person who makes unplanned purchases.

P4: When I see something that really interests me, I buy it without thinking about the consequences.
P5 (reverse item): I avoid buying things that are not on my shopping list.

The operationalization of PFM (which the authors called the FMB scale) was carried out by using a 15-item scale (see items in Table 1), created by Dew and Xiao (2011), presumably with the factor structure of a second-order-four-dimension construct. The authors used a representative sample of 1,011 Americans, corroborating the scale psychometric properties $($ alpha $=.81)$ and validity, and found a strong correlation with predictive measures of financial behavior such as level of savings and indebtedness. In our research, we also back-translated our version of the PFM scale into English.

In the original study by Dew and Xiao (2011), the factor analysis of the proposed PFM scale produced a solution with four factors, which explained $59 \%$ of the data variance. After oblique rotation, the identified factors, with corresponding items in the research questionnaire, were reproduced in Table 1 . The authors called the factors F1 (savings and investments), F2 (insurance), F3 (cash management), and F4 (credit management).

We added FS as a consequent construct of PFM, in order to test its predictive validity and, in combination with BI, its nomological validity.

The FS construct was operationalized by Mills et al., (1992) using a Likert scale. With evidence of unidimensionality and reliability (alpha $=0.81)$, it is a short scale that is useful to appraise the effect of PFM. The four FS items were:

T1: I often experience money problems.

T2: I spend a lot of time worrying about financial matters.

T3: Financial problems often interfere with my work or daily routine.

T4: Financial problems interfere with my relationships with other people. 
Table 1

\section{Exploratory factor analysis of pfm scale}

\begin{tabular}{|c|c|c|c|c|}
\hline Item & Factor 1 & Factor 2 & Factor 3 & Factor 4 \\
\hline R1 ('Comparison shop’) & & & .73 & \\
\hline R2 ('Pay bills on time') & & & .64 & \\
\hline R3 ('Keep a financial record') & & & .69 & \\
\hline R4 ('Stay within budget') & & & .66 & \\
\hline R11 ('Pay off credit card') & & & & $.66^{(*)}$ \\
\hline R12 ('Max out credit card') (R) & & & & .77 \\
\hline R13 ('Make minimum payment on loans') (R) & & & & .72 \\
\hline R21 ('Maintain or create an emergency fund') & .73 & & & \\
\hline R22 ('Save from every paycheck') & .75 & & & \\
\hline R23 ('Save for a long-term goal other than retirement') & .78 & & & \\
\hline R24 ('Save for retirement') & .69 & & & \\
\hline R25 ('Invest money') & .70 & & & \\
\hline R31 ('Obtain or maintain proper health insurance') & & .85 & & \\
\hline R32 ('Obtain or maintain proper property insurance') & & .74 & & \\
\hline R33 ('Obtain or maintain proper life insurance') & & .80 & & \\
\hline Eigenvalues & 4.43 & 1.84 & 1.31 & 1.25 \\
\hline$\%$ Variance explained by factor (total explained $=59 \%$ ) & $30 \%$ & $12 \%$ & $9 \%$ & $8 \%$ \\
\hline
\end{tabular}

Note. ${ }^{(*)}$ the item R11 also had a significant loading in factor $1 .{ }^{(\mathrm{R})}$ Reverse item. Factors extracted by principal component analysis, using Kaiser's criterion (retention of factors whose eigenvalues are higher than one) and oblique promax rotation. Adapted from "The Financial Management Behavior scale: development and validation" from J. Dew and J.J. Xiao, 2011, Journal of Financial Counseling and Planning, 22 (1), 49.

To assess the quality of the operationalization of the constructs of the research model, we followed two procedures. We verified the dimensionality of the presumably unidimensional constructs - BI and FS - by exploratory factor analysis (EFA) and estimated their reliability using Cronbach's Alpha, before appraising their validity. Confirmatory factor analysis (CFA) was performed in an integrative way in the assessment of the research measurement model (Figure 1).

Personal Financial Management, the research focus, and presumably a secondorder construct with four dimensions, was appraised using CFA. Its composite reliability and convergent, discriminant, and predictive validity were checked by testing the relationship between PFM and the BI and FS constructs (nomological validity).
A measure's dimensionality refers to the homogeneity of its indicators. In unidimensional measures, the single factor or latent variable accounts for most of the variance associated with the interrelationship between their items.

Gerbing and Anderson (1988) recommend using exploratory factor analysis (EFA) to check the unidimensionality of a construct, assessing whether the number of retained factors in the factor analysis using principal component analysis is one, by adopting the Kaiser criterion (eigenvalues higher than 1) to define the number of factors.

In order to assess the fitness of factor solutions to data, some authors suggest that the inverse correlation matrix $\mathbf{R}_{(p x p)}^{-1}$ needs to be close to the diagonal matrix (Rencher, 2002; apud Mingoti, 2005). As a result, some heuristics recommended by Hair et al. (2009) - 
KMO (Kaiser-Meyer-Olkin) measure > .6 and significant Bartlett's sphericity test - are used to check if the linear correlations between variables allow the extraction of consistent factors in the EFA (Mingoti, 2005).

In the EFA of unidimensional scales, when only one factor is retained (by applying the Kaiser criterion: eigenvalue $>1$ ) in the factor extraction with principal component analysis, the percentage of variance accounted for by the retained factor is expected to be at least $60 \%$. The unidimensionality of a (sub)scale to measure a construct is a requisite for assessing its reliability or internal consistency using the Cronbach alpha, where the minimum is .6 in exploratory studies and .7 in confirmatory ones (Netemeyer et al., 2003).

In order to assess the reliability of multidimensional constructs, many authors (e.g. Hair et al., 009; Netemeyer et al., 2003) recommend calculating composite reliability and the average variance extracted (AVE). Like the Cronbach alpha, composite reliability is an index of internal consistency of the items of a scale, which must be at least .6 for short scales (Netemeyer et al., 2003). According to Fornell and Larcker (1981), the formula to calculate composite reliability is as follows:

$$
\text { Comp. Reliab. }=\frac{\left(\sum_{i=1}^{p} \lambda_{i}\right)^{2}}{\left(\sum_{i=1}^{p} \lambda_{i}\right)^{2}+\sum_{i}^{p} V(\delta)}
$$

Where:

$\lambda_{\mathrm{i}}=$ standardized loading of each $i$ th indicator $\mathrm{V}\left(\delta_{\mathrm{i}}\right)=$ error variance for the $i$ th indicator $r=$ number of indicators

In the composite reliability (CR) calculation, Hair et al. (2009) explain that we should not consider the negative loadings in the totalization of standardized loadings. Moreover, they remind us that $\boldsymbol{V}(\delta)$ is the measurement error for each indicator, obtained as:
$1-$ Reliability $=1-\lambda_{\mathrm{i}}^{2}$.

Another measure to estimate the internal consistency of a construct, also used to check convergent validity, is the estimation of average variance extracted (AVE) (formula 2), which measures the amount of variance captured by a set of items, related to the measurement error. Fornell and Larcker (1981) argue that AVE should be $>.50$.

$A V E=\frac{\sum_{i=1}^{p} \lambda_{i}^{2}}{p}$

Where:

$\lambda_{\mathrm{i}}=$ standardized loading of each $i t h$ indicator $r=$ number of indicators

Construct validity is the congruence between the measured attribute (indicator) and the construct which it aimed to operationalize (Netemeyer et al., 2003). The two most common types of construct validity are convergent and discriminant validity.

Convergent validity corresponds to the level that different methods of measuring the attributes of the same construct lead to sufficiently correlated results (Bagozzi \& Yi, 1993). It is possible to test convergent validity by using CFA, according to Gerbing and Anderson (1998). In two stages, the authors recommend a procedure to assess a structural model. Firstly, we use CFA to test the measurement model, that is, we estimate a model with only the relationships between constructs and their respective indicators allowing only covariances between latent variables. In this stage, we also check the dimensionality of constructs, reliability, and convergent, discriminant, and predictive validity. If we consider the structural model to be valid, then, in the second stage, by using structural equations modeling (SEM), we assess the structural relationships between latent variables. Note that we must carry out the analysis in the 
context of the model or nomological network examined.

To test whether the constructs had convergent validity, we employed CFA in the measurement model of the network encompassing BI, PFM, and FS, i.e., a model with the construct and their respective indicators, allowing covariances only between the latent variables (Figure 1). We checked the factor loading significance and the percentage of variance accounted for by the corresponding constructs, which should be higher than $50 \%$, according to Hair et al. (2009). The rationale behind this convergent validity analysis procedure is the assumption that indicators of the same construct can be interpreted as their different measurements and thus must converge.

Discriminant validity evaluates whether measures of conceptually distinct constructs are not confounded such that, if it is significant, their correlation is not so great that they are not distinguished. To test discriminant validity, we used the procedure recommended by Fornell and Larcker (1981): we calculated the correlations between the constructs and the square roots of their respective average variances extracted (AVEs). Two constructs have discriminant validity if the absolute value of their correlation is smaller than the square root of the AVE of each one.

\section{Results}

In the sample, there was a balance between men (48.5\%) and women $(51.5 \%)$ and a predominance of individuals (76\%) with a family income higher than five minimum wages, i.e., monthly income greater than $\mathrm{R} \$ 4,400$ (four thousand and four hundred Brazilian reais).

The results were analyzed using the Microsoft Excel $2010^{\circ}$ software and the IBM SPSS $2^{1^{\circ}}$ and AMOS $21^{\circ}$ statistical packages.

In the analysis of univariate outliers, we detected lower (below $\mathbf{Q}_{\mathbf{1}}-\mathbf{1 . 5}$ IQR) and higher (above $\mathbf{Q}_{3}+\mathbf{1 . 5} \mathrm{IQR}$ ) extreme values, where IQR is the interquartile range, between $\mathrm{Q} 3$ and Q1, where $50 \%$ of the data of any distribution are concentrated.
No variable presented both upper and lower extreme values at the same time. As a more robust variability estimator for non-normal distributions, the interquartile range (IQR) as a reference for univariate outlier detection is suggested by Tukey (1977), who considers outlier values outside the range $\left(Q_{1}-\mathbf{1 . 5} I Q R\right.$, $\left.\mathbf{Q}_{3}-1.5 \mathrm{IQR}\right)$. This criterion is adopted in the boxplot graphics of software such as $\mathrm{SPSS}^{\oplus}$ when univariate extreme values are detected.

There was no evidence that the outliers detected were anomalous observations. To avoid a considerable reduction of the sample, by elimination of questionnaires, analyses were performed, keeping the detected univariate outliers. However, in order to mitigate their effect, all the lower extreme values were replaced in a single round by measures at a position above the scale and the upper extreme values by measures at a position below the scale, as suggested by Tabachnick and Fidell (1996). After attenuating the effects of the extreme values, new analyses detected the emergence of other data as outliers, although in a very low number. After treating the univariate extreme values, multivariate outliers were detected, using the Mahalanobis distance, which takes into account covariances, assuming correlation between variables and differences in dispersion (Mingoti, 2005). Due to the extremely low number of multivariate outliers, the two identified cases were retained for further analysis.

Due to the use of electronic data collection, we did not have problems of missing data, except in the cases of answers related to the option NA ('not applicable') in two items of the PFM scale, as described further below.

Firstly, we did the exploratory factor analysis (EFA) of the Buying Impulsiveness (BI) and Financial Strain (FS) scales, to check their dimensionality (Netemeyer et al. 2003). In the case of BI (Weun et al., 1997) and FS (Mills et al., 1992), according to the original scales sources, the expectation was to obtain unidimensional and internally consistent solutions. In the case of PFM, the assumption was that it was a four- 
factor scale, whose structure was similar to the one revealed by Dew and Xiao (2011).

In the EFA of Impulsiveness, extracting factors by principal component analysis, we obtained an admissible solution $(\mathrm{KMO}=.81$, significant Bartlett's sphericity test, $p<.01)$. The percentage of variance accounted for by the first factor was $56 \%$. To guarantee unidimensionality, we dropped the item with the lowest loading, reverse item P5 ('I avoid buying things that are not on my shopping list'). As a result, the variance accounted for by the first factor $(66.3 \%)$ exceeded $60 \%$. The factor solution was acceptable (KMO $=.80$ and significant Bartlett's sphericity test).

Having deleted an item, the BI's Cronbach alpha rose to .82 , overcoming the minimum level of internal consistency for a unidimensional scale (Netemeyer et al., 2003).

In the EFA of Financial Strain, we also extracted factors by using principal component analysis. The factor solution was admissible $(\mathrm{KMO}=0.74$, significant Bartlett's sphericity test, $p<.01)$, and the percentage of variance accounted for by the first factor was 59\%. For unidimensionality, we dropped one scale's item: T2 ('I spend a lot of time worrying about financial matters'). With the remaining three items, the FS scale showed unidimensionality because the percentage of tor variance accounted for by the first factor was $70 \%$. This factor solution was also acceptable (KMO $=.67$ and significant Bartlett's sphericity test). The TF scale's Cronbach alpha also overcame the minimum level of .60 .

According to the EFA and Cronbach alpha results, we conclude that, after deleting one item of each one, the BI and FS scales became unidimensional and had internal consistency.
In this research, we deleted two items of the PFM from further analyses $(\mathrm{R} 4=$ Stayed within the budget or spending plan' and R13 = 'Made only the minimum payment on a loan'), due to answers of the 'Not applicable' type, taken as legitimate cases of missing data.

Taking for granted the factor solution found by Dew and Xiao (2011), i.e., interpreting PFM as a second-order-four-factor construct, we assessed its reliability and validity in the context of the model that relates Financial Management to Buying Impulsiveness and Financial Strain: BI $\rightarrow$ PFM $\rightarrow$ FS

By using the maximum likelihood method, we estimate the goodness of fit index and measurement model's coefficients, with the results of the confirmatory factor analysis of the three constructs shown in Figure 1.

The measurement model showed a satisfactory fit $(\chi 2=275.83$, d.f. $=162, p<.01$, $\chi 2 /$ d.f. $=1.70$, CFI $=.91$, TLI $=.90$, RMSEA $=.06$, PCLOSE $=.09)$. According to $\mathrm{Hu}$ and Bentler (1999), CFI index (Index of Comparative Fit) values higher than .90 are acceptable, even though values over .95 are recommended. Normalized chi-square ( $\chi 2 /$ d.f.) values must be lower than 2 or 3 (Schreiber, Nora, Stage, Barlow, \& King 2006). Due to its sensitivity to the number of model parameters, the RMSEA (Root Mean Square Error of Approximation) index is considered as one of the most informative, with $\mathrm{Hu}$ and Bentler (1999) recommending that its value be equal or lower than .06. In the measurement model, the constructs and subconstructs showed significant loadings $(p<.05)$ in all their respective indicators, and the expected significant covariances between the constructs were detected. 


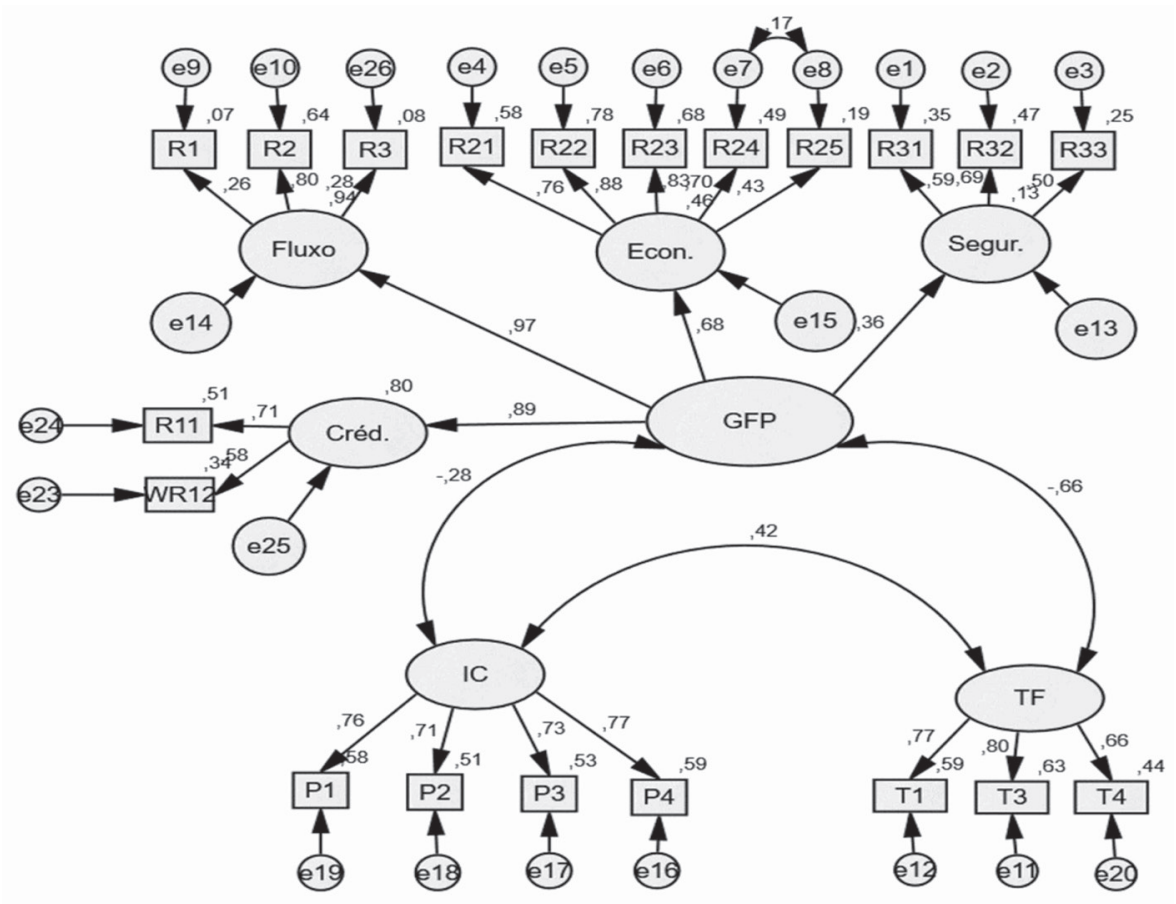

$$
\begin{array}{r}
\text { Qui_Quad = 275,834 } \\
\text { G.L. }=162 \\
\text { Qui_Quad_N=1,703 } \\
\text { CFI }=, 914 \\
\text { TLI }=, 899 \\
\text { RMSEA }=, 060 \\
\text { PCLOSE }=, 086
\end{array}
$$

Figure 1. Standardised estimates of the measurement model $(\mathrm{n}=195)$

Note. WR12 is the codification of the reverse item R12 (see Table 1). Cash., Econ., Insur., and Cred. abbreviate the names given to the PMF dimensions (see Method).

These results reinforce the plausibility of the proposed model and hence the evidence of the reliability and validity of the associated constructs.
Based on the estimation of the model, the indexes shown in Table 2 certify reliability and construct validity (convergent and discriminant validity).

Table 2

Construct's reliability and validity $(\mathrm{n}=195)$

\begin{tabular}{lccccc}
\hline & CR & AVE & BI & PFM & FS \\
\hline BI & .830 & .551 & .742 & & \\
PFM & .836 & .584 & -.282 & .764 & \\
FS & .787 & .553 & .421 & -.658 & .744 \\
\hline
\end{tabular}

Note. BI (Buying Impulsiveness), PFM (Personal Financial Management), FS (Financial Strain), CR (Composite Reliability), and AVE (Average Variance Extracted).

The Composite Reliability $(\mathrm{CR}) \geq .60$ shows reliability, even though some authors say that .60 is only acceptable in exploratory studies (e.g., Ab Hamid, Sami, \& Sidek, 2017). The CR higher than .60 and AVE $\geq .50$ show convergent validity (Netemeyer et al., 2003). The correlations 
between constructs are under the diagonal in the gray part of the table. Moreover, in the diagonal, in bold, the square root of AVEs must be higher than the module of the corresponding Pearson correlations to indicate the discriminant validity of each construct of one pair considered.

The predictive and nomological validities of PFM were checked, by testing the hypotheses of the negative effect of BI on PFM (H1), the positive effect of $\mathrm{BI}$ on $\mathrm{FS}(\mathrm{H} 2)$, and the negative effect of PFM on FS (H3).

Two nested models were compared, by using the difference of chi-squares. The first one, less restrictive, assumed that PFM partially mediates the relationship between BI and FS, i.e., the three effect hypotheses are true. The second model, nested in the previous one and more restrictive, presumed that the PFM totally mediates the relationship between BI and FS, i.e., there is no direct effect from BI on FS (only the first and third hypotheses are true). The results of the estimation of the first model (partial mediation) are shown in Figure 2.

The fit indexes of model 1 - in which PMF is a partial mediator - are the same as the measurement model previously mentioned and, hence, are satisfactory $(\chi 2=275.83$, d.f. $=162$, $p<.01, \chi 2 /$ d.f. $=1.70$, CFI $=.91$, TLI $=.90$, RMSEA $=.06$, PCLOSE $=.09$ ), as previously explained in the assessment of the measurement model.

Taking model 1 as valid, we also estimate the results of model 2 (PFM is the total mediator between Buying Impulsiveness and Financial Strain and, as a result, the direct effect of BI on FS is null), nested in model 1 .

The difference in the models' chi-squares $\left(\Delta \chi 2=9.223\right.$ with $\left.\Delta_{\text {D.F. }}=1\right)$ is significant $(p<.01)$. Thus, model 1 (partially mediated) is preferable to model 2 (totally mediated).

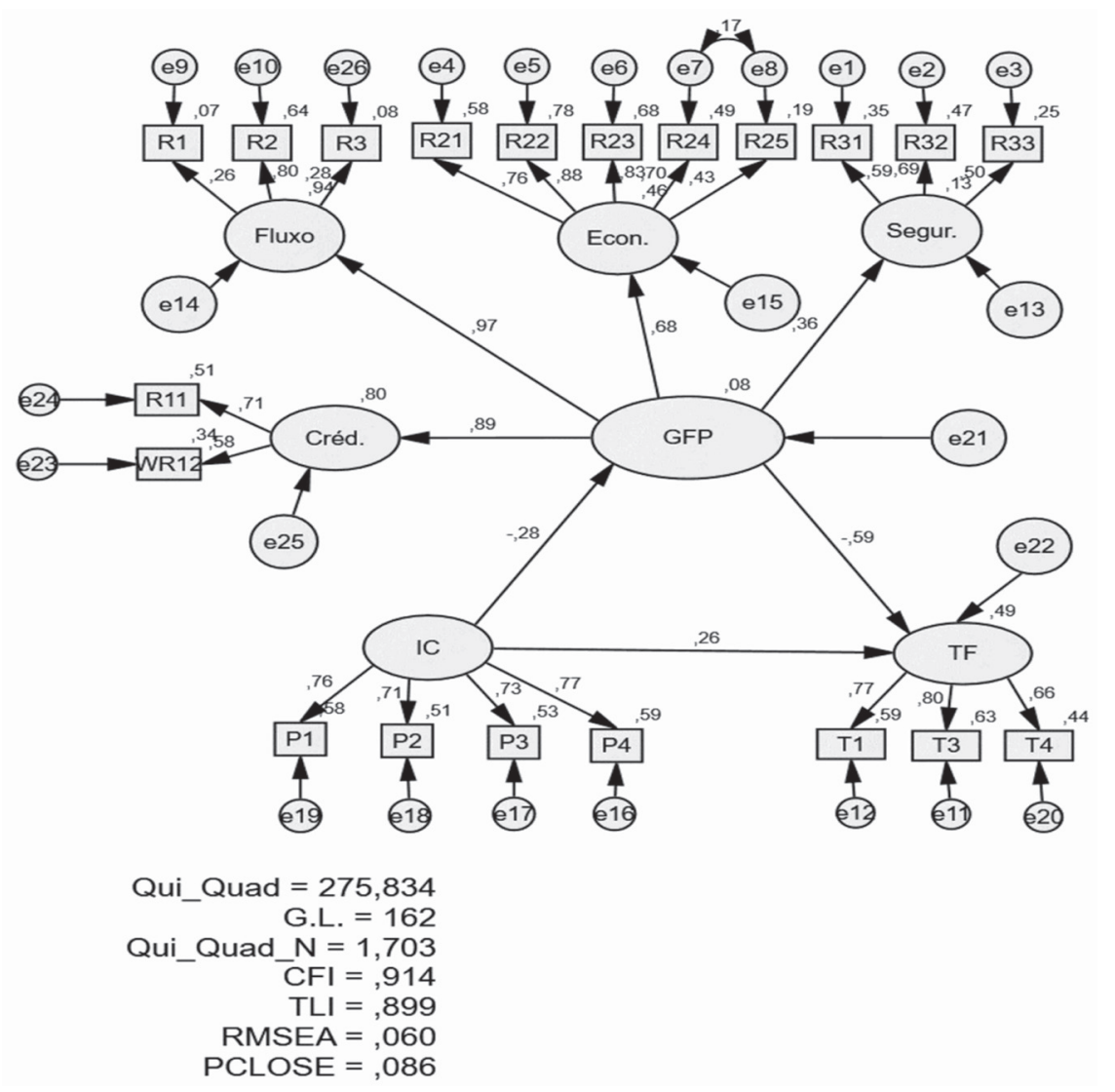

Figure 2. Standardized estimates of the partial mediation model ( $\mathrm{n}=195)$ 
In this model (PFM is the partial mediator between $\mathrm{BI}$ and FS), the percentages of the variance accounted for of the endogenous constructs are: $\mathrm{R}_{\text {PFM }}^{2}=8 \% ; \mathrm{R}_{\text {FS }}^{2}=49 \% ; \mathrm{R}_{\text {Cred. }}^{2}=80 \% ; \mathrm{R}_{\text {Flux. }}^{2}=$ $94 \% ; \mathrm{R}_{\text {Sav. }}^{2}=46 \% ; \mathrm{R}_{\text {Insur. }}^{2}=13 \%$.
Based on the estimated effects in model 1, Table 3 shows that the three research hypotheses were supported. The standardized values of these effects are, respectively, -.28, .26, and -.59 (see Figure 2).

Table 3

\section{Hypotheses test results}

\begin{tabular}{ccccc}
\hline Hypothesis & Effect & Expected signal & Non-standardized coefficient with $\boldsymbol{p}$-value & Result \\
\hline H1 & BI on PFM & Negative & $t=-.25 p<.01$ & Supported \\
H2 & BI on FS & Positive & $t=.26, p<.01$ & Supported \\
H3 & PFM on FS & Negative & $t=-.66, p<.01$ & Supported \\
\hline
\end{tabular}

Note. BI (Buying Impulsiveness), PFM (Personal Financial Management) and FS (Financial Strain).

\section{Implications of Results and Final Comments}

The empirical test, in Portuguese, of the Personal Financial Management, Buying Impulsiveness, and Financial Strain scales showed evidence of good psychometric properties, in terms of dimensionality, reliability, and construct validity, based on an internet survey of Brazilian respondents.

The model used to check the predictive and nomological validity of the focal construct - PFM - involved, besides testing the scale, examining the relationship with an antecedent construct (BI) and a consequent construct (FS), in order to appraise its consistency and practical usefulness.

As a theoretical contribution, the empirical support of the research hypotheses - PMF has a negative effect on FS and partially mediates the effect of BI on FS - encourages the use of the PFM scale to appraise personal financial competence and the constructs related with it.

In practice, analyzing the multidimensional construct of PFM provides important information for both financial education programs and market segmentation. Of the four dimensions - Savings and Investments, Insurances, Cash Management, and Credit Management -PFM apparently manifests more strongly in the Management of Cash Flow $\left(\mathrm{R}_{\text {Cred. }}^{2}=80 \% ; \mathrm{R}_{\text {Flux. }}^{2}=94 \% ; \mathrm{R}_{\text {Sav. }}^{2}\right.$
$=46 \% ; \mathrm{R}_{\text {Insur. }}^{2}=13 \%$ ), the behaviors of which probably immediately reveal a Personal Financial Management standard. Such a result suggests that behaviors such as comparing prices, paying bills on time, keeping a record of expenses, staying within a budget or spending plan, and not accumulating excessive debts characterizes proper PFM more clearly than investing over a longterm basis and keeping insurance. Thus, a good financial education must begin with teaching good management of funds and checking accounts, if this result is confirmed in other studies.

Evidence of the predictive validity of the PFM construct was obtained by verifying its negative association with Financial Strain in the Brazilian context, thus corroborating previous results, which show that individuals with inadequate resources management behaviors tend to be more stressed and have more financial concerns. Competent personal financial management can effectively contribute to reducing financial hardship, overcoming conditions that generate dissatisfaction and stress.

The effect of Buying Impulsiveness on Financial Strain requires further investigation. The results showed that the partially mediated model is preferable to the fully mediated model; that is, BI exerts both a positive direct effect and an indirect negative effect on Financial Strain, via PFM. Perhaps the more individuals buy impulsively, the more insecure they are about their ability 
to afford spending and potential indebtedness, raising their financial worries, but that effect can be mitigated by sound personal management of financial resources.

The results suggest that consumers educated to reduce their impulsiveness, by increasing self-control, can decrease their impulse purchases, thereby reducing the impact on their stress or financial strain.

Methodologically, we believe that this study contributes to consolidating good practices for evaluating, adapting, and using marketing and management scales, thus contributing to their theoretical development and management applications.

Despite the consistent and promising results, the study presents limitations related to the research method, sampling, attenuated presence of outliers in the data, and elimination of some items of the scales. Inferred causal relations are speculative, notwithstanding their plausibility. The sample of higher education respondents is not representative of the adult Brazilian population. Therefore, further studies with larger and diversified samples may better describe the financial management behavior patterns of the Brazilian adult population.

As more advanced research, we recommend using the validated scales to investigate of the personality traits that explain buying impulsiveness, personal financial management, and financial strain. These personality traits can be used in consumer segmentation, when choosing specific communication associated with financial education programs, and to develop more adequate financial services, taking into account the characteristics of the target population and the relationship between these characteristics and personal financial management, their antecedents, and consequents.

\section{References}

Ab Hamid, M. R., Sami, W., \& Sidek, M. M. (2017). Discriminant Validity Assessment: Use of Fornell \& Larcker criterion versus HTMT
Criterion. In Journal of Physics: Conference Series, 890(1), p. 012163. IOP Publishing.

Academia Brasileira de Ciências (2013). Rigor e integridade na condução da pesquisa científica - guia de recomendaçóes de práticas responsáveis, 2013. Retrieved from https://www.abc.org.br/ IMG/pdf/doc-4311.pdf

Amar, M., Ariely, D., Ayal, S., Cryder, C. E., \& Rick, S. I. (2011). Winning the battle but losing the war: The psychology of debt management. Journal of Marketing Research, 48(SPL), 38-50.

Archuleta, K. L., Britt, S. L., Tonn, T. J., \& Grable, J. E. (2011). Financial satisfaction and financial stressors in marital satisfaction. Psychological Reports, 108(2), 563-576.

Bagozzi, R. P., \& Yi, Y. (1993). Multitraitmultimethod matrices in consumer research: critique and new developments. Journal of Consumer Psychology, 2(2), 143-170.

Campara, J. P., Vieira, K. M., \& Ceretta, P. S. (2016). Entendendo A Atitude Ao Endividamento: Fatores Comportamentais E Variáveis Socioeconômicas O Determinam?. Revista Eletrônica de Ciência Administrativa, 15(1), 5.

Confederação Nacional do Comércio de Bens, Serviços e Turismo (2017). Pesquisa Nacional de Endividamento e Inadimplência do Consumidor. Retrieved from http://cnc.org.br/sites/default/ files/arquivos/analise_peic_outubro_2017.pdf

Conto,S.M., Faleiro, S. N., Fürh, I.J., \& Kronbauer, K. A. (2015). O comportamento de alunos do ensino médio do Vale do Taquari em relação às finanças pessoais. Revista Eletrônica de Estratégia \& Negócios, 8:2, 182-206.

Cronbach, L. J., \& Meehl, P. E. (1995). Construct validity in psychological tests. Psychological Bulletin, 52(4), 281.

Dew, J., \& Xiao, J. J. (2011). The Financial Management Behavior scale: development and 
validation. Journal of Financial Counseling and Planning, 22 (1), 43-87.

Falahati, L., Sabri, M. F., \& Paim, L. H. (2012). Assessment a model of financial satisfaction predictors: Examining the mediate effect of financial behavior and financial strain. World Applied Sciences Journal, 20(2), 190-197.

Farrell, L., Fry T. \& Risse, L. (2015) The significance of financial self-efficacy in explaining women's personal finance behaviour. Journal of Economic Psychology, 54, 85-99.

Figueira, R., F. \& Pereira, R. C. F. (2014). Devo, Não Nego, Pago Quando Puder: uma Análise dos Antecedentes do Endividamento do Consumidor. Revista Brasileira de Marketing, 13(5).

Flake, J. K.; Pek, J., \& Hehman, E. (2017). Construct validation in social and personality research: Current practice and recommendations. Social Psychological and Personality Science, 8(4), 370-378.

Fornell, C., \& Larcker, D. F. (1981). Evaluating structural equation models with unobservable variables and measurement error. Journal of Marketing Research, 39-50.

Gerbing, D. W., \& Anderson, J. C. (1988). An updated paradigm for scale development incorporating unidimensionality and its assessment. Journal of Marketing Research, 186-192.

Hair, J. F., Black, W. C., Babin, B. J., \& Anderson, R. E. (2009). Multivariate Data Analysis. Upper Saddle River, NJ: Prentice hall.

Hu, L. T., \& Bentler, P. M. (1999). Cutoff criteria for fit indexes in covariance structure analysis: Conventional criteria versus new alternatives. Structural equation modeling: a multidisciplinary journal, 6(1), 1-55.

Joo, S. (2008). Personal financial wellness. In Handbook of consumer finance research (pp. 21-33). Springer New York.
Joo, S. H., \& Grable, J. E. (2004). An exploratory framework of the determinants of financial satisfaction. Journal of family and economic Issues, 25(1), 25-50.

Kamleitner, B., Hoelzl, E. \& Kirchler, E. (2012). Credit use: Psychological perspectives on a multifaceted phenomenon. International Journal of Psychology, 47 (1), 1-27.

Lynch, J. (2011) Introduction to the Journal of Marketing Research Special Interdisciplinary Issue on Consumer Financial Decision Making. Journal of Marketing Research: November 2011, Vol. 48, No. SPL, pp. Siv-Sviii.

Medeiros, F. G., Diniz, I. S. F. N, Costa, F. J., \& Pereira, R. D. C. F. (2015). Influência de estresse, materialismo e autoestima na compra compulsiva de adolescentes. RAC-Revista de Administração Contemporânea, 19(2), 138-155.

Medeiros, S.F. \& Lopes, T.A. (2014). Finanças pessoais: um estudo com alunos do curso de Ciências Contábeis de uma IES privada de Santa Maria - RS. Revista Eletrônica de Estratégia \& Negócios, 7:2, 221-251.

Mendes-da-Silva, W., Nakamura, W. T. \& Moraes, D. C. (2012). Credit card risk behavior on college campuses: evidence from Brazil. BAR. Brazilian administration review, 9, 351-373.

Mills, R. J., Grasmick, H. G., Morgan, C. S., \& Wenk, D. (1992). The effects of gender, family satisfaction, and economic strain on psychological well-being. Family Relations, 440-445.

Mingoti, S. A. (2005). Análise de dados através de métodos de estatística multivariada: uma abordagem aplicada. Editora UFMG.

Miotto, A. P. S., \& Parente, J. (2015). Antecedentes e consequências do gerenciamento das finanças domésticas na classe média baixa brasileira. $R A E-$ Revista de Administração de Empresas, 55(1), 50-64. 
Moreira, R.M. \& Carvalho, H. L. (2013). As finanças pessoais dos professores da rede municipal de ensino de Campo Formoso-BA: Um estudo na Escola José de Anchieta. Revista de Gestão, Finanças e Contabilidade,. 3:1,122-137.

Netemeyer, R. G., Bearden, W. O., \& Sharma, S. (2003). Scaling procedures: Issues and applications. Sage Publications.

Norvilitis, J. M. \& Mendes-Da-Silva, W. (2013) Attitudes toward Credit and Finances among College Students in Brazil and the United States. Journal of Business Theory and Practice, 1:1, 132-151.

Norvilitis, J. M., Merwin, M. M., Osberg, T. M., Roehling, P. V., Young, P., \& Kamas, M. M. (2006). Personality factors, money attitudes, financial knowledge and credit card debt in college students. Journal of applied social psychology, 36, 1395-1413.

Piccoli, M. R. \& Silva, T. P. (2015). Análise do nível de educação em gestão financeira dos funcionários de uma instituição de ensino superior. Economia e Gestão, 15:41,112-134.

Pirog S.F. \& Roberts J.A. (2007) Personality and Credit Card Misuse Among College Students: The Mediating Role of Impulsiveness, Journal of Marketing Theory and Practice, 15:1, 65-77.

Podsakoff, P. M., MacKenzie, S. B., Lee, J. Y., \& Podsakoff, N. P. (2003). Common method biases in behavioral research: A critical review of the literature and recommended remedies. Journal of applied psychology, 88(5), 879.

Rook, D. W., \& Fisher, R. J. (1995). Normative influences on impulsive buying behavior. Journal of Consumer Research, 22(3), 305-313.

Serviço de Proteção ao Crédito \& Confederação Nacional de Dirigentes Lojistas (2017). Consequências da inadimplência nas emoçóes, relacionamentos e saúde. Retrieved from https://www.spcbrasil.org.br/ wpimprensa/wp-content/uploads/2017/10/
SPC-Analise-Consequ\%C3\%AAncias-daInadimpl\%C3\%AAncia-2017.pdf

Schreiber, J. B., Nora, A., Stage, F. K., Barlow, E. A., \& King, J. (2006). Reporting structural equation modeling and confirmatory factor analysis results: A review. The Journal of educational research, 99(6), 323-338.

Spinella, M., Yang, B. \& Lester, D. (2007). Development of the executive personal finance scale. International Journal of Neuroscience, 117:301-313.

Strauss, M. E., \& Smith, G. T. (2009). Construct validity: Advances in theory and methodology. Annual review of clinical psychology, 5, 1-25.

Strömbäck, C., Lind, T., Skagerlund, K., Västffäll, D. \& Tinghög, G.(2017). Does self-control predict financial behavior and financial wellbeing? Journal of Behavioral and Experimental Finance, 14, 30-38.

Tabachnick, B. G., \& Fidell, L. S. (1996). Using Multivariate Statistics, $3^{\text {rd }}$ ed, HarperCollins. New York.

Tang, N. \& Baker, A. (2016). Self-esteem, financial knowledge and financial behavior. Journal of Economic Psychology, 54,164-176.

Trindade, L. L., Righi, M. B., \& Vieira, K. M. (2012). De onde vem o endividamento feminino? Construção e Validação de um modelo PLS-PM. Revista Eletrônica de Administração, 73(3), 718-746.

Tukey, J. (1977). Exploratory data analysis. Addison-Wesley.

Weun, S., Jones, M. A., \& Beatty, S. E. (1997). A parsimonious scale to measure impulse buying tendency. AMA Educators' Proceedings: Enhancing Knowledge Development in Marketing, 306-307.

Zimmerman, S. L. (1995). Understanding family policy: Theories and applications. Sage. 


\section{Supporting Agencies:}

Conselho Nacional de Desenvolvimento Científico e Tecnológico - CNPQ

"We are very grateful to CNPq for the funding of the research, and to the respondents for their collaboration"

\section{About the Authors:}

1. Ricardo Teixeira Veiga, PhD in Administration, Federal University of Minas Gerais, Belo Horizonte, Brazil. E-mail: ricardo.necc@gmail.com

ORCID

(iD)0000-0001-5467-0972

2.Cátia Fabíola Parreira de Avelar, Master in Administration, Federal University of Minas Gerais, Belo Horizonte, Brazil. E-mail :catiaavelar@yahoo.com.br

ORCID

(iD) 0000-0001-8026-7490

3.Luiz Rodrigo Cunha Moura, PhD in Administration, Federal University of Minas Gerais, Belo Horizonte, Brazil. E-mail: luizrcmoura@gmail.com

ORCID

(DD0000-0002-7040-7864

4.Agnaldo Keiti Higuchi, PhD in Administration, Federal University of Minas Gerais, Belo Horizonte, Brazil. E-mail: agnaldo.higuchi@gmail.com

ORCIID

(iD)0000-0001-8719-6154

\section{Contributions of each author}

\begin{tabular}{|c|c|c|c|c|}
\hline Contribution & $\begin{array}{c}\text { Ricardo } \\
\text { Teixeira Veiga }\end{array}$ & $\begin{array}{c}\text { Cátia Fabíola } \\
\text { Parreira de Avelar }\end{array}$ & $\begin{array}{l}\text { Luiz Rodrigo } \\
\text { Cunha Moura }\end{array}$ & $\begin{array}{l}\text { Agnaldo Keiti } \\
\text { Higuchi }\end{array}$ \\
\hline 1. Definition of research problem & $\sqrt{ }$ & & & \\
\hline $\begin{array}{l}\text { 2. Development of hypotheses or research questions (empirical } \\
\text { studies) }\end{array}$ & $\sqrt{ }$ & $\sqrt{ }$ & & \\
\hline \multicolumn{5}{|l|}{ 3. Development of theoretical propositions (Theoretical Work) } \\
\hline 4. Theoretical foundation/ Literature review & $\sqrt{ }$ & $\sqrt{ }$ & & \\
\hline 5. Definition of methodological procedures & & & $\sqrt{ }$ & $\sqrt{ }$ \\
\hline 6. Data collection & & & $\sqrt{ }$ & $\sqrt{ }$ \\
\hline 7. Statistical analysis & $\sqrt{ }$ & $\sqrt{ }$ & & \\
\hline 8. Analysis and interpretation of data & $\sqrt{ }$ & $\sqrt{ }$ & $\sqrt{ }$ & $\sqrt{ }$ \\
\hline 9. Critical revision of the manuscript & & & $\sqrt{ }$ & $\sqrt{ }$ \\
\hline 10. Manuscript Writing & $\sqrt{ }$ & $\sqrt{ }$ & & \\
\hline 11. Other (please specify which) & & & & \\
\hline
\end{tabular}

